\title{
Implementation of Criminal Action Prosecution Online in Realizing Principle of Fast Prosecution, Simple \& Low Cost
}

\author{
Ardito Yudho Pratomo*), Umar Ma'ruf ${ }^{* *}$ and Aryani Witasari***) \\ *) Subsidiary for the Prosecution of General Crimes at the Wonogiri State \\ Prosecutor's Office, E-mail: ardhito_yudho@ymail.com \\ ${ }^{* *}$ ) Lecturer of Master of Law, Faculty of Law, Universitas Islam Sultan Agung \\ Semarang. \\ $*^{* *}$ ) Lecturer of Master of Law, Faculty of Law, Universitas Islam Sultan Agung \\ Semarang.
}

\begin{abstract}
Indonesia is a state of law, thus everything is regulated by law, if there are people who violate the law then it is resolved through a judicial process. The Covid-19 virus has had an impact on the need for online trials. The formulation of the problem in this study is how the implementation and constraints of the implementation of the stages of prosecuting criminal cases (online) and how the ideal implementation in the application of the stage of prosecuting criminal cases (online) in order to realize the principles of fast, simple and low-cost justice in Indonesia. Wonogiri Prosecutor's Office? This study uses empirical legal research methods. The results of this study indicate that the implementation of the stages of prosecuting criminal cases (online) in order to realize the principles of fast, simple and low-cost justice at the Wonogiri Prosecutor's Office is carried out with Supreme Court Regulation (PERMA) No. 1 of 2019 concerning Administration and Trial in Courts Electronically. Implementation constraints in the application of (online) prosecution of criminal cases due to legal factors, Cultural Community facilities and infrastructure. The ideal implementation of the application of online criminal prosecution in order to realize the principles of fast, simple and low-cost justice at the Wonogiri Prosecutor's Office requires clear arrangements, human resources who have IT skills. Internet Network, a good understanding of the law intensively conduct outreach to the community.

Keywords: Prosecution; Crime; Covid-19.
\end{abstract}

\section{Introduction}

Indonesia is the largest archipelagic country in the world, with a large population distribution as well. ${ }^{1}$ With such a large population, to regulate social life and create social order, a rule of law is needed. Wi: Prosecution; Crime; Covid-19.th this state of law, no one is above the law, the law is in power and also the administration of government must be based on law. ${ }^{2}$

But right now the global world is facing the problem of a virus pandemic known as the corona virus. The coronavirus pandemic itself is an ongoing pandemic of the coronavirus disease 2019 (Covid-19), caused by severe acute respiratory syndrome

\footnotetext{
${ }^{1}$ Malta and Smardjo. (2018). Keberdaan Transmigran dalam Berusahatani di Kabupaten Banyuasin dan Ogan Ilir Provinsi Sumatra Utara, Jurnal Penyuluhan, Vol.14. No.2, Bogor, p. 1. Jurnal.ipb.ac.id/index.php.jupe/article/view/19039.

${ }^{2}$ Achmad Irwan H. (2014). Menggagas Indonesia sebagai Negara hukum yang membahagiakan rakyatnya, Jurnal Yustisia, Vol.90, p.136. jurnal.uns.ac.id/yustisia/article/view/29562
} 
(SARS-CoV-2). ${ }^{3}$ Indonesia is one of the countries that has also been affected by the spread of the Covid-19 virus, which has spread to 34 provinces. ${ }^{4}$ This Covid-19 pandemic ultimately has an impact in several fields or sectors, one of which is the law enforcement process which is also affected, namely the difficulty in completing the handling of legal cases.

A criminal act with the term criminal act which is an act that is prohibited by a legal regulation, where the prohibition is accompanied by the threat of sanctions in the form of certain crimes for anyone who violates the prohibition. ${ }^{5}$ The settlement of criminal cases is carried out through the evidentiary process, namely the prosecution process which is carried out directly in a trial. However, due to the Covid-19 pandemic, in the end it became an obstacle.

E-court itself has basically been regulated in the Regulation of the Supreme Court of the Republic of Indonesia Number 1 of 2019 concerning Case Administration and electronic court trials. This arrangement aims to make the trial run effectively and efficiently. And with Covid-19, this is a moment to improve the implementation of eCourts in Indonesia.

However, the legitimacy of proving criminal cases online due to the Covid-19 pandemic is still on its way to date, however, there are pros and cons. There is still an assumption that the implementation of this online criminal trial violates several rules in the Criminal Procedure Code which requires witness examination to be carried out in the Court's courtroom. To fill the void in online criminal trial rules and as a follow-up to the MoU between law enforcement agencies, the Supreme Court is currently preparing a draft PERMA regarding this online/online trial arrangement. The substance that is planned to be regulated in the PERMA includes, among others, implementing justice in a simple, fast and low cost way.

Based on the background of the problem above, the purpose of this writer is to explain and find out the implementation and obstacles to the implementation of the stages of prosecuting criminal cases (online). To explain the ideal implementation in the implementation of the (online) prosecution of criminal cases due to the Covid-19 pandemic at the Wonogiri District Attorney.

\section{Research Method}

This research is a sociological or empirical legal research. ${ }^{6}$ The nature of this research is descriptive research. ${ }^{7}$ Qualitative approach using content analysis. The data sources in this study are divided into two data sources, namely (1) Primary Data, namely data obtained directly from the source or the first data source where a data is generated. ${ }^{8}$ (2) Secondary data is complementary data which will later be explicitly correlated with primary data, including in the form of books, journals, and magazines. Data collection

\footnotetext{
${ }^{3}$ https://en.m.wikipedia.org/wiki/2019-20_coronavirus_pandemic accessed on April 6, 2020 at 00:36 WIB.

${ }^{4}$ https://id.m.wikipedia.org accessed on Monday, July 13, 2020 at 20.00 WIB.

${ }^{5}$ Ismu Gunadi and Jonaedi Efendi. (2014). Hukum Pidana. Jakarta: Kencana, p. 3.

${ }^{6}$ Soerjono Soekamto. (2008). Pengantar Penelitian Hukum. Jakarta: UI Press, p.52.

${ }^{7}$ Sarifuddin Azwar. (1998). Metode Penelitian. Yogyakarta: Pustaka Pelajar, p.7.

${ }^{8}$ Lexy J. Moleong. (2010). Metodologi Penelitian Kualitatif, Bandung: Remaja Rosdakarya Offset, p. 112.
} 
methods researchers use interviews, observations, literature study. ${ }^{9}$ Legal Material Analysis Techniques which are carried out by examining, examining the data that have been obtained are then presented in narrative form, then the data is connected with theories and laws and regulations so that answers to the problems in this study are obtained.

\section{Results and Discussion}

\subsection{Implementation and constraints of online prosecution to realize fast, simple, low-cost justice}

3.1.1. Implementation in the field stages of prosecuting criminal acts (online) due to the Covid-19 pandemic

The product of a law or system must be more flexible in accordance with the rapid progress and development of the times. ${ }^{10}$ One of them is an online trial. According to Horn, implementation is actions carried out by individuals or officials or government or private groups that are directed to efforts to achieve goals that have been outlined in a policy. ${ }^{11}$ In the implementation of the stages of prosecuting criminal cases online, the legal basis used is the Mondeling Procedure (Oral and Indonesian Language Procedures-153 paragraph (2) of the Criminal Procedure Code). Criminal Case Trials are held via electronic means (video conference) arranged through the letter of the Director General of Badilum MARI No: 379/DJU/PS.00/3/2020 (27 March 2020), RI Attorney General's Letter No: B-049/A/SUJA /03/2020 (27 March 2020).

In addition, the arrangement is through a Cooperation agreement between: THE SUPREME COURT OF THE REPUBLIC OF INDONESIA, THE RI Attorney General's Office, the RI MINISTRY OF LAW AND HUMAN RIGHTS, Number: 402/DJU/HM.01.1/4/2020, Number: KEP-17/E/Ejp/04/ 2020, Number: PAS-08.HH.05.05 OF 2020, About

The electronic justice system (E-Litigation) is the implementation of Supreme Court Regulation (PERMA) no. 1 of 2019 concerning Administration and Trial in Courts Electronically. PERMA No. 1 of 2019 is complementary to PERMA No. 3 of 2018 concerning Administration in Electronic Courts (e-court). E-Court includes case registration (e-filling); down payment of court fees (e-payment); court summons \& notification (e-summons).

E-litigation in PERMA runs the trial process electronically (exchange of court documents (lawsuits, requests, resistance, answers, replicas, duplicates, conclusions); evidence; pronouncement of decisions; and sending decisions to the parties electronically). Several arrangements regarding the electronic trial are regulated in several articles, namely as follows:

Article 2 paragraph (2)

\footnotetext{
${ }^{9}$ Nasution. (1996). Metode Research (Penelitian Ilmiah). Jakarta: Bumi Aksara, p.106.

${ }^{10}$ I Dewa Putu. (2018). Formulasi Model Sistem Pemidanaan Anak di Indonesia, Jurnal Daulat Hukum master of law faculty of law Univeristas Islam Sultan Agung, Vol.1, No. 1 (2018), p.1. Jurnal. Unissula.ac.id/index.php. RH/Issue/view/247

${ }^{11}$ Arifin Tahir. (2014). Kebijakan Publik dan Tranparansi Penyelenggaraan Pemerintah Daerah, Batinggi, Bandung, p. 55.
} 
- Judge Council, Substitute Registrar, Prosecutor convening in the courtroom, the defendant attends the trial from the detention center where the defendant is detained accompanied/without being accompanied by a legal advisor;

- The Judge Council, Substitute Registrar, convenes in the courtroom, the Prosecutor attends the trial from the Prosecutor's Office, the defendant is accompanied/without the assistance of his Legal Counsel attends the trial from the Rutan where the defendant is detained;

- In the event that the place where the defendant is detained does not have special facilities to attend the trial electronically, the defendant accompanied/not accompanied by a legal advisor attends the trial from the Prosecutor's Office or

- The accused who is not detained may attend the trial in the Court's Courtroom or from the Prosecutor's Office accompanied/unaccompanied by a Legal Counsel or other place approved by the Judge panel;

- It was explained that it was the prosecutor's obligation to present the defendant to trial, so that if it was at the prosecutor's office, the obligation to present and secure the defendant had been fulfilled if it is outside the prosecutor's office, the risk is greater.

3.1.2. Implementing obstacles in the application of online prosecution of criminal cases due to the Covid-19 pandemic

The theory of legal effectiveness requires aspects that support and support all law enforcement actions, Soerjono Soekanto mentions that the factors that influence law enforcement are determined by the legal factors themselves, law enforcement factors, advice or facilities factors, community factors, namely the environment in which the law applies or is enforced, and cultural factors. Where each description above by the author is described as follows: ${ }^{12}$

a) The legal factor

The legal factor is related to the laws and regulations governing an act which in this case by the author is the regulation regarding the conduct of the trial through online which is caused due to the Covid-19 pandemic.

As mentioned above, if the law has been regulated in Supreme Court Regulation (PERMA) No. 1 of 2019. However, the arrangements in it have not been regulated in detail and clearly. There are still several articles that should be regulated in the Criminal Procedure Code but in this PERMA it is not regulated thus creating a legal confusion for the conduct of the trial.

b) Law Enforcement Factor

The criminal justice system as a law enforcement system using criminal law, does not run optimally and has an impact on law enforcement performance, thus it will be difficult to achieve its function, as an effort to combat crime. ${ }^{13}$ The law enforcement factor is a very important factor in the conduct of the trial. One of the state apparatus authorized to carry out law enforcement

\footnotetext{
${ }^{12}$ Soerjono Soekanto. (2008). Faktor-Faktor Yang Mempengaruhi Penegakan Hukum, Jakarta: PT RajaGrafindo Persada, p.8-37.

${ }^{13}$ Achmad Budi Waskito. (2018). Impelementasi Sistem Peradilan Pidana Dalam Perspektif Integrasi, Jurnal DAULAT Hukum Master of law faculty of law, Universitas Islam Sultan Agung, Vol 1, No. 1 (2018) p. 1. jurnal. Unissula.ac.id/index.php./RH/Issue/284.
} 
duties is the Prosecutor. ${ }^{14}$ This law enforcement factor can be determined from the number of personnel, human resources. Regarding the number of personnel, both prosecutors and prosecutors' administrative staff, in terms of the ideal number, it is inadequate, but in an emergency condition of the Covid19 pandemic, it is quite adequate. However, in relation to conducting online trials, the prosecutor's office actually needs someone who has the ability or expertise in the IT field, so that if there are obstacles that cause bad or lost connections or other problems, they can be resolved quickly and the trial can take place without interruption.

c) Facilities and infrastructure

Facilities and infrastructure are very important to be fulfilled in order to support the implementation of the trial. In an emergency at the Wonogiri Prosecutor's Office, the trial implementation during the Covid-19 pandemic was adequate, but it could still be improved with various services, both the prosecutor's and witness' waiting rooms, the convenience of witnesses while waiting to be summoned for trial with various facilities and innovations, for example, drinking, snacks, reading books/magazines, or free wifi. Especially the basic facilities for the availability and stability of the internet network for online courts.

As stated by the convict Ruslan Ardianto who said that the facilities and infrastructure were up to standard, but sometimes the voice was not heard clearly. The voice of the Wonogiri District Court has been heard clearly, but the voice of the Wonogiri District Court is sometimes intermittent. ${ }^{15}$

d) Public

The community here is someone who is directly involved in the trial process which in this case is the defendant and the convict. In the implementation of the trial, the community still experiences confusion, this is as conveyed by the convict Sulistyono who stated that he did not understand the trial procedure. The trial is like a game but the punishment is real. ${ }^{16}$ Thus, providing understanding to the community is a good priority because the understanding of the defendant and the community in practice is still very minimal.

e) Culture

Culture is something that is usually carried out in society and has become a culture and routine to be carried out. In this case, the trial is carried out conventionally. Associated with the online trial is something new and thus is still an obstacle in the implementation of socialization. Because good socialization when connected to the Covid-19 pandemic emergency is an alternative solution to problems in law enforcement, especially the implementation of the trial if it is carried out conventionally or offline, it is feared that there will be crowds and the potential for transmission of Covid-19.

\footnotetext{
${ }^{14}$ Syahida, Agung, Bayu. (2014). Implemntasi Perda Nomor 14 Tahun 2009 Tentang pengelolaan Sampah di Kota Tanjungpinang, (studi Ksus di Kelurahan Tanjung Unggat), Univeritas Meda Area, p. 13.

${ }^{15}$ Ruslan Ardianto, Convict, Personal Interview, Wonogiri, 3 May 2021, 11:00 WIB.

${ }^{16}$ Sulistyanto, Convict, Personal Interview, Wonogiri, 3 May 2021, 11:30 WIB.
} 
Thus, the community or defendant can adapt to the implementation of the new trial and does not cause any confusion by the defendant.

\subsection{The ideal application of online prosecution in realizing fast, simple, low-cost justice}

Based on the constraints as stated above, in this case an ideal implementation is needed in the application of online criminal prosecution, so the author in this case provides several ideas and suggestions based on the constraints presented above, namely as follows:

Legal Factor; Regulations that can be accepted by all interested parties and do not cause harm to either party. Because as mentioned above, if there are still many legal factors, such as the unregulated judicial apparatus (Judges, Prosecutors, Witnesses, Experts, Defendants and Legal Counsels) which virtually replaces physical presence at the trial, it has not been regulated in the Criminal Procedure Code, in addition to the process of probate. . Thus, there is a need for clear arrangements and no overlapping regulations in conducting online trials. Due to the fact that online trials can be carried out properly, the principle of fast, simple and low-cost justice can be realized.

Law enforcer; Prevention and prosecution through law enforcement must be carried out comprehensively so that the implementation of law enforcement can run effectively. ${ }^{17}$ There needs to be changes and additions to human resources who have the ability in the IT field. This need for human resources is very much needed because there is someone who has the ability in the IT field, if there are connection problems or problems in the conduct of the trial, they can be handled quickly. In addition, members of the public prosecutor's office are also provided with adequate capabilities related to IT and training so that the principles of quick, simple and light justice can be carried out properly with this online trial.

Facilities and infrastructure; For facilities and infrastructure that need to be improved is the internet network where at the time of trial there are often delays making it difficult for litigants, especially when listening to witnesses, because that is a very important thing in a proof in a criminal case. There is a need for additional facilities and infrastructure considering that previously the position of the trial was at the district court office to be the district attorney's office for prosecutors and witnesses, so that the availability of fulfillment of facilities and infrastructure automatically changes and increases in order to be comfortable and can provide excellent service to the community, for the fulfillment of these activities, there is also something that can be taken from the budget either through the mechanism of budget preparation or revision.

Public; The public is given a good legal understanding regarding the implementation of this online trial. Changing the habits of people who always rely on physical contact is forced to make adjustments by implementing physical distancing. The community is viewed from two sides, namely as victims and on the other hand as witnesses. Not

\footnotetext{
17 Hulman Siregar. (2018). Rumusan Pidana dan pemidanaan Tindak Pidana Korupsi Yang Merugikan Keuangan Negara Serta Permasalahan Dalam Penerapannya, Jurnal Daulat Hukum Master of law Faculty of law Universitas Islam Sultan Agung, Vol.1 No.1 (2018), p.1. jurnal. Unissula.ac.id/index.php./RH/Issue/284.
} 
everyone wants to be a witness for various reasons. So if there are people who want to be witnesses, it would be great to be given excellent service, for example completing various conveniences and speeding up the waiting time for witnesses to convene.

Culture; The ideal condition in this cultural factor is even better if the relevant parties are more aggressive in conducting socialization to the community so that all elements of society are expected to know the legal developments that occur and make the community more aware of the legal provisions.

Culture is more towards habit, there is a Javanese proverb "Iso Soko Kulino". For online hearings, it is a new thing to make it a habit or habit, we must get used to it. If it can later be created a new culture. Thus, periodic and periodic socialization is needed so that the online trial can be carried out.

\section{Closing}

First, the implementation and obstacles in the implementation of the stages of prosecuting criminal cases (online) in order to realize the principles of fast, simple and low-cost justice at the Wonogiri Prosecutor's Office carried out by Supreme Court Regulation (PERMA) No. 1 of 2019 concerning Administration and Trial in Courts Electronically. PERMA No. 1 of 2019 is complementary to PERMA No. 3 of 2018 concerning Administration in Electronic Courts (e-court). The obstacle the legal factor creates a legal confusion for the implementation of the trial. The enforcement factor requires someone who has the ability or expertise in the IT field. Facilities and infrastructure need to be improved. Society lacks socialization. Culture related to online trials is something that needs to be socialized. Second, the ideal implementation of the application of the prosecution of criminal cases (online) legal factors need clear arrangements and no overlapping regulations in the implementation of online trials. Law enforcers need changes and additions to human resources who have capabilities in the IT field. Facilities and infrastructure that need to be improved is the internet network. The public needs to be given a good understanding of the law.

Next can be suggested, First, for the Indonesian government and the House of Representatives to provide clear regulations relating to the implementation of online trials clearly and if necessary changes to the Criminal Procedure Code in addition to provide socialization on its implementation. Second, for law enforcers to carry out online trials optimally so that the principles of a fast, simple and low cost trial can be realized by having an online trial.

\section{References}

\section{Journals:}

[1] Achmad Budi Waskito. (2018). Impelementasi Sistem Peradilan Pidana Dalam Perspektif Integrasi, Jurnal DAULAT Hukum Master of law faculty of law, Universitas Islam Sultan Agung, Vol 1, No. 1 (2018) p. 1. jurnal. Unissula.ac.id/index.php./RH/Issue/284.

[2] Achmad Irwan H. (2014). Menggagas Indonesia sebagai Negara hukum yang membahagiakan rakyatnya, Jurnal Yustisia, Vol.90, p.136. jurnal.uns.ac.id/yustisia/article/view/29562 
[3] Hulman Siregar. (2018). Rumusan Pidana dan pemidanaan Tindak Pidana Korupsi Yang Merugikan Keuangan Negara Serta Permasalahan Dalam Penerapannya, Jurnal Daulat Hukum Master of law Faculty of law Universitas Islam Sultan Agung, Vol.1 No.1 (2018), p.1. jurnal. Unissula.ac.id/index.php./RH/Issue/284.

[4] I Dewa Putu. (2018). Formulasi Model Sistem Pemidanaan Anak di Indonesia, Jurnal Daulat Hukum master of law faculty of law Univeristas Islam Sultan Agung, Vol.1, No. 1 (2018), p.1. Jurnal. Unissula.ac.id/index.php.RH/Issue/view/247

[5] Malta and Smardjo. (2018). Keberdaan Transmigran dalam Berusahatani di Kabupaten Banyuasin dan Ogan Ilir Provinsi Sumatra Utara, Jurnal Penyuluhan, Vol.14. No.2, Bogor, p. 1. Jurnal.ipb.ac.id/index.php.jupe/article/view/19039.

\section{Books:}

[1] Arifin Tahir. (2014). Kebijakan Publik dan Tranparansi Penyelenggaraan Pemerintah Daerah, Batinggi, Bandung

[2] Ismu Gunadi and Jonaedi Efendi. (2014). Hukum Pidana. Jakarta: Kencana

[3] Lexy J. Moleong. (2010). Metodologi Penelitian Kualitatif, Bandung: Remaja Rosdakarya Offset

[4] Nasution. (1996). Metode Research (Penelitian Ilmiah). Jakarta: Bumi Aksara

[5] Sarifuddin Azwar. (1998). Metode Penelitian. Yogyakarta: Pustaka Pelajar

[6] Soerjono Soekamto. (2008). Pengantar Penelitian Hukum. Jakarta: UI Press

[7] Soerjono Soekanto. (2008). Faktor-Faktor Yang Mempengaruhi Penegakan Hukum, Jakarta: PT RajaGrafindo Persada

[8] Syahida, Agung, Bayu. (2014). Implemntasi Perda Nomor 14 Tahun 2009 Tentang pengelolaan Sampah di Kota Tanjungpinang, (studi Ksus di Kelurahan Tanjung Unggat), Univeritas Meda Area

\section{Internet:}

[1] https://en.m.wikipedia.org/wiki/2019-20_coronavirus_pandemic accessed on April 6, 2020 at 00:36 WIB.

[2] https://id.m.wikipedia.org accessed on Monday, July 13, 2020 at 20.00 WIB. 